\title{
ENERGETIC EFFICIENCY OF A DEEP BED SWINE PRODUCTION SYSTEM
}

\section{ALESSANDRO V. VELOSO ${ }^{1}$, ALESSANDRO T. CAMPOS ${ }^{2}$, VANDERSON R. DE PAULA $^{3}$, DAVID C. DOURADO ${ }^{4}$, TADAYUKI YANAGI JÚNIOR ${ }^{5}$, ENILSON B. SILVA ${ }^{6}$}

\begin{abstract}
The aim of this work was to evaluate the energy flows of a commercial production system of swine deep bed in its finishing phase, located in Juiz de Fora, in the State of Minas Gerais, Brazil. Thus, an energy efficiency study was carried out by monitoring a lot of animals, during a 94-day period. The energy rate of each compound involved in the production process was quantified and the matrixes of energy consumption were determined in the form of animal feeding, electrical energy, piglets, material used as deep bed, human labor, equipment, swine buildings, production of alive swine for slaughter, organic fertilizer production (swine deep bed or swine deep litter). From the direct input energy, $80.57 \%$ correspond to animal feeding, $11.90 \%$ to pigs for slaughter and $6.76 \%$ to piglets, while from the energy output $53.45 \%$ correspond to the terminating swine and $46.55 \%$ to organic fertilizer (swine deep bed). By the results obtained, we can conclude that such production system has corresponded to an industrial and highly specialized agro ecosystem, importing a great part of the energy consumed in the production process, with $41 \%$ of energy efficiency.
\end{abstract}

KEYWORDS: Energy input and output, swine buildings, alternative management, sustainability of biosystems.

\section{EFICIÊNCIA ENERGÉTICA DE UM SISTEMA DE PRODUÇÃO DE SUÍNOS EM CAMA SOBREPOSTA}

RESUMO: O objetivo deste trabalho foi avaliar os fluxos de energia de um sistema comercial de produção de suínos em cama sobreposta da fase de terminação, localizado em Juiz de Fora - MG. Para tanto, realizou-se estudo de eficiência energética, por meio do acompanhamento de um lote de animais, durante o período de 94 dias. Quantificou-se o coeficiente energético de cada componente envolvido no processo de produção e determinaram-se as matrizes de consumo energético nas formas de ração, energia elétrica, leitões, material usado como cama, mão de obra, equipamentos, instalações, produção de suínos vivos, e produção de adubo orgânico (cama sobreposta de suíno). Da energia direta de entrada, 80,57\% correspondem à ração, $11,90 \%$ à serragem e $6,76 \%$ aos leitões. Da energia de saída, 53,45\% referem-se aos suínos para abate e 46,55\% ao adubo orgânico (cama sobreposta de suíno). Pelos resultados obtidos, pode-se concluir que o sistema de produção em questão se enquadrou nas características de um agroecossistema industrial, altamente especializado, importando grande parte da energia consumida no processo de produção e apresentando eficiência energética de $41 \%$.

PALAVRAS-CHAVE: Balanço de energia, instalações para suínos, manejo alternativo, sustentabilidade de biossistemas.

\footnotetext{
${ }^{1}$ Zootecnista, Doutorando em Engenharia Agrícola, Setor de Construções e Ambiência, Departamento de Engenharia, Universidade Federal de Lavras (DEG/UFLA). Membro do Grupo de Pesquisa em Construções e Ambiência em Biossistemas (COAMBI), veloso.alessandrovieira@yahoo.com.br.

${ }^{2}$ Professor Adjunto, Setor de Construções e Ambiência, Departamento de Engenharia, Universidade Federal de Lavras (DEG/UFLA). Coordenador do Grupo de Pesquisa em Construções e Ambiência em Biossistemas (COAMBI).

${ }^{3}$ Doutorando em Engenharia Agrícola, Setor de Máquinas e Mecanização, Departamento de Engenharia, Universidade Federal de Lavras (DEG/UFLA). Professor do Instituto Federal de Educação, Ciência e Tecnologia do Sul de Minas.

${ }^{4}$ Doutorando em Eng. Agrícola, Setor de Máquinas e Mecanização, Depto. de Engenharia, Univ. Federal de Lavras (DEG/UFLA).

${ }^{5}$ Professor Associado, Setor de Construções e Ambiência, Departamento de Engenharia, Universidade Federal de Lavras (DEG/UFLA). Membro do Grupo de Pesquisa em Construções e Ambiência em Biossistemas (COAMBI).

${ }^{6}$ Professor Associado, Departamento de Agronomia, Universidade Federal dos Vales do Jequitinhonha e Mucuri (FCA/UFVJM). Recebido pelo Conselho Editorial em: 14-6-2012
} Aprovado pelo Conselho Editorial em: 25-6-2012 


\section{INTRODUCTION}

Agriculture and cattle raising, as its demands in society grow for food and raw materials, its role in manufacturing and consuming energy is also greatly emphasized. In the agricultural production process, beyond the energy found freely in nature, there is an intense use of energy added by man, especially those stemming from fossil fuels. This production model, consisting of the breeding of animals and plants, the use of inputs and machinery, to the detriment of the benefits related to increased production and productivity, has contributed to the depletion of natural resources, compromising the sustainability of agro ecosystems (SANTOS \& SIMON, 2010).

In this context, the power consumption to be the basis of productive activities, leads inevitably to an impact on the environment, therefore, necessary to improve efficiency in processing (production and final consumption), transportation and distribution, as well as the provision waste (COSTA \& BUENO, 2010).

Therefore, it is important to consider the pig activity, which, in the past 30 years, has achieved high levels of productivity with the intensification of confined systems that predict large concentration of animals in small areas, generating consequently large amounts of waste pollutants (Angonese et al., 2007; DAGA et al., 2007; KUNZ et al., 2009; ORRICO JR et al., 2011). Facing environmental swine culture matters, alternatives involving changes in the shape of animal husbandry and manure management have been proposed, among them the rearing of pigs in deep bed (CORRÊA et al., CORRÊAA, 2009; et al., 2008; COSTA et al., 2008).

However, it is important to consider that the entire production process generates waste and all waste stores energy and, in this context, production systems, including the pig holdings, can store such waste into energy, lowering production costs and operating with an energy-balanced way (SANTOS \& LUCAS JÚNIOR, 2004; SOUZA et al., 2009).

Thus, the importance of energy balance in agricultural systems has been demonstrated by several researchers (ANGONESE et al. 2,006; BIAGGIONI \& BOVOLENTA, 2010; CAMPOS et al. 2,009; CAMPOS et al. 2005; CAMPOS et al. 2,004 ; CAMPOS et al., 2003; FRIGO et al., 2011; JASPER et al., 2010; MELO et al., 2007; SANTOS \& LUCAS JÚNIOR, 2004; SOUZA et al., 2009), and is based on the physical principle of energy conservation, also known as the first principle of thermodynamics, i.e., the energy variation in a process can be explained by the energy balance, i.e. energy inputs and outputs (ANGONESE et al., 2006).

The energy balance aims to establish the energy flows, identifying its total demand, energy efficiency reflected by the net energy gain and the relative input / output (converted energy / energy consumed) and energy needed to produce one kilogram of process or a product. In this process, all the inputs are quantified and converted, which are transformed into energy units (CAMPOS et al., 2005). This procedure allows the determination of the processes, materials and equipment to higher energy consumption, indicating savings options (CAMPOS et al., 2003).

The analysis of agro ecosystems from the perspective of their energy flows can be an instrument for assessing the energy balance in swine production systems (ANGONESE et al., 2006; SOUZA et al., 2009) and are related-indicators of energy, besides they constitute promising technical approach to evaluate and investigate problems related to energy efficiency and sustainability of agricultural systems (ANGONESE et al., 2006).

From what has been exposed, the aim of this study was to evaluate the energy flows in a shed for the production of pigs in deep bed, checking forms of direct and indirect energy involved in its production process.

\section{MATERIAL AND METHODS}

The study was conducted at Fazenda Penalva, where there is a unit of growing-finishing pigs in deep bed system, with an installed capacity to 1.200 animals, located in the city of Juiz de Fora - 
MG, at a latitude of $21^{\circ} 41$ ' 20 " South and longitude $43^{\circ} 20^{\prime} 40^{\prime \prime}$ West, with an average altitude of $785.5 \mathrm{~m}$. The climate is Caw type, tropical altitude, with dry and cold winters, rainy and warm summers (CONDÉ, 2006).

The production system of pigs in deep bed has as principle the replacement of conventional floor for a bed of about $0.50 \mathrm{~m}$ thick consisting of carbon-rich materials, which performs the dual function of the manure digester floor and which are retained, stored and stabilized within the pig building, managed and treated in solid state through the composting process, providing cost reduction in buildings, improving the welfare of animals and causing less impact on the environment (CORRÊA et al., 2009 ; CORRÊA et al., 2008; COSTA et al., 2008; TAIT et al., 2009).

The building that held the production unit had the following design characteristics: $1489.86 \mathrm{~m}^{2}$, ceiling height of four $\mathrm{ft}$, metal walls along the shed, roof with fiber cement tiles on metal structure and eaves of $1.32 \mathrm{~m}$ that led the rainwater outside.

The used substrate was eucalyptus sawdust. In the area destined to the formation of the bed, the shed was filled with one layer of $0.45 \mathrm{~m}$ thick of this substrate. The stocking density used in these units was $1.24 \mathrm{~m}^{2}$ per animal.

The system was limited by activities related to the receiving of piglets, treatment and leaving of pigs for slaughter which cover animals in the finishing phase (32 to 106kg of live weight), besides the inclusion of all processes, costs and energy generation embedded in a swine confinement unit that uses the litter system.

The study was based on estimates of inputs and outputs energy obtained during the monitoring of a batch or cycle, i.e., since the arrival of piglets to the production unit to their leaving for slaughter, corresponding to a period of 94 days.

The efficiency $(\eta)$ was obtained by the following equation reported by ANGONESE et al. (2006), MELO et al. (2007), SANTOS \& LUCAS JÚNIOR (2004) and SOUZA et al. (2009):

$$
\eta=\frac{\sum \text { EOutput }}{\sum \text { EConsume }}
$$

Where:

$\sum \mathrm{E}_{\text {Output }}=\sum\left(\mathrm{E}_{\text {DOutput }}+\mathrm{E}_{\text {IOutput }}\right)$

$\sum \mathrm{E}_{\text {Consume }}=\sum\left(\mathrm{E}_{\mathrm{DConsume}}+\mathrm{E}_{\mathrm{IConsume}}\right)$;

$\mathrm{E}_{\mathrm{D}}=$ Direct energy estimative;

$\mathrm{E}_{\mathrm{I}}=$ Indirect energy estimative;

$\mathrm{E}_{\text {Output }}=$ Useful energy estimative which comes out during the production process (in the form of product);

$\mathrm{E}_{\text {Consume }}=$ Consumed energy estimative in the production process.

Considering the same procedure adopted by ANGONESE et al. (2006) and SOUZA et al. (2009), as direct energy were used the ones related to water, fuel, electricity, grease, piglets, lubricants, human labor, feed and sawdust used as bedding, while for indirect energy were considered the ones used in the facilities and in the manufacture of machinery and implements.

Using methodology recommended by ANGONESE et al. (2006), it was considered as useful energy, live pigs for slaughter and organic fertilizer in the form of swine deep bed.

Figure 1 summarizes the energy components (input and output) unit involved in the production of pigs in litter. 


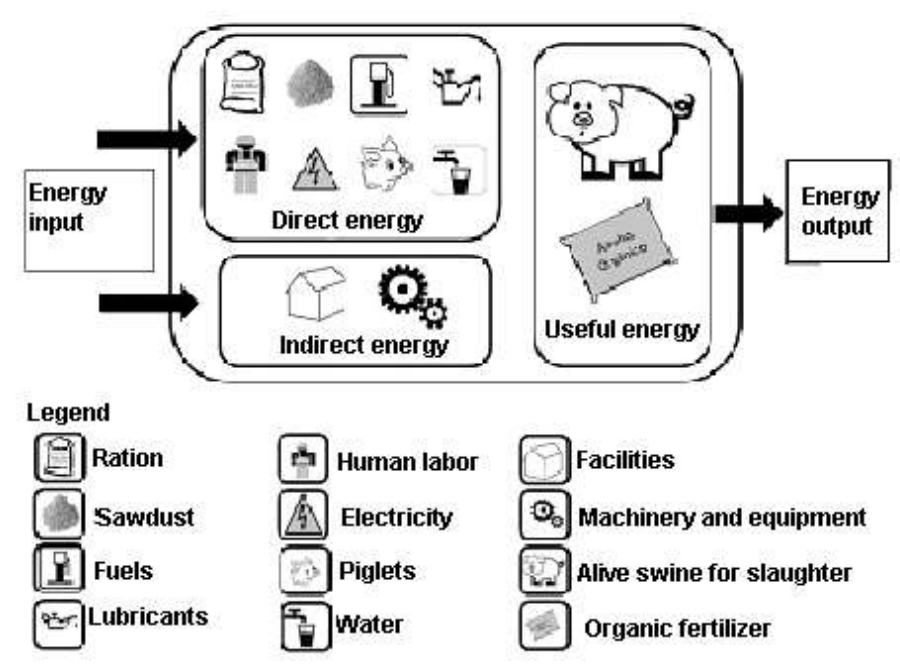

FIGURE 1. Energy flow in the production system of swine deep bed.

To obtain the coefficients of energy, a transformation in units of caloric input components involved in such system was done, following the energy coefficients established by several authors, as shown in Table 1.

In terms of the components of the energy outputs of the production of pigs in deep bed and their energy coefficients, which have been based on information contained in ANGONESE et al. (2006), the energy coefficient for pigs for slaughter was $9.21 \mathrm{MJ} \mathrm{kg}^{-1}$. On the other hand, the energy of organic fertilizer in the swine deep bed format was determined by using bomb calorimeter PARR 1261, according to the methodology described in SANTOS \& LUCAS JÚNIOR (2004), where we got the value of $14.55 \mathrm{MJ} \mathrm{kg}^{-1}$.

TABLE 1. Energy inputs components related to swine deep bed production system and its respective energy coefficients.

\begin{tabular}{|c|c|c|c|}
\hline Input components & Coefficients & Measure & Lifespan \\
\hline Human labor ${ }^{1,1 a}$ & 4.39 & $\mathrm{MJ} \operatorname{man~}^{-1}$ & - \\
\hline Equipment $^{1}$ & 83.71 & $\mathrm{MJkg}^{-1}$ & 30 \\
\hline Electricity $^{2}$ & 3.60 & MJkWh $^{-1}$ & - \\
\hline Iron $^{1}$ & 62.78 & $\mathrm{MJkg}^{-1}$ & 20 \\
\hline $\mathrm{PVC}^{1}$ & 119.99 & $\mathrm{MJkg}^{-1}$ & 40 \\
\hline Foundation/concrete ${ }^{3}$ & 641.64 & $\mathrm{MJm}^{-3}$ & - \\
\hline Concrete floor $^{3}$ & 86.33 & $\mathrm{MJm}^{-2}$ & - \\
\hline Ration $^{4}$ & 17.00 & $\mathrm{MJkg}^{-1}$ & - \\
\hline Plastic $^{4}$ & 130.04 & $\mathrm{MJkg}^{-1}$ & - \\
\hline Electric wire $^{4}$ & 45.02 & $\mathrm{MJkg}^{-1}$ & - \\
\hline Fiber cement tiles $^{3}$ & 3.93 & $\mathrm{MJkg}^{-1}$ & - \\
\hline Brick wall $^{3}$ & $1,208.17$ & $\mathrm{MJm}^{-2}$ & - \\
\hline Piglets $^{4}$ & 9.21 & $\mathrm{MJkg}^{-1}$ & - \\
\hline Water $^{1}$ & 2.37 & $\mathrm{MJm}^{-3}$ & - \\
\hline Diesel oil $^{1}$ & 47.48 & $\mathrm{MJ}^{-1}$ & - \\
\hline Lubrificating oils $^{5}$ & 37.75 & $\mathrm{MJ}^{-1}$ & - \\
\hline Grease $^{5}$ & 43.38 & $\mathrm{MJkg}^{-1}$ & - \\
\hline Sawdust used as bed ${ }^{6}$ & 17.95 & $\mathrm{MJkg}^{-1}$ & - \\
\hline
\end{tabular}


Based on the coefficients of energy input and output, for the calculations of the energy conversion of some energy components involved in the production shed for swine deep bed, we have used the equations contained in SANTOS \& LUCAS JUNIOR (2004), such as:

- Ration: (quantity, kg of natural material) x (energy ratio, $\mathrm{MJkg}^{-1}$ );

- Sawdust and organic fertilizer in the form of swine deep bed: (quantity, kg of natural material) $x$ (energy ratio, $\mathrm{MJkg}^{-1}$ );

- Electricity: (consumption, $\mathrm{kWh}$ ) $x$ (energy ratio, $\mathrm{MJ} \mathrm{kWh}^{-1}$ );

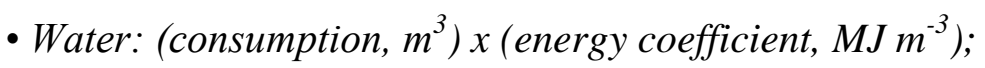

- Human labor: (hours man worked ${ }^{-1}$ ) x (energy ratio, man $\mathrm{MJ}^{-1}$ );

- Piglets and pigs for slaughter (quantity, kg of natural material) x (energy ratio, $\mathrm{MJ} \mathrm{kg}^{-1}$ ).

For the most accurate calculation of energy consumption related to the structure of the shed for the swine deep bed, the energy option was chosen for a more detailed composition, applying the values of the energy of the different materials used in construction, as reported by ANGONESE et al. (2006) and CAMPOS et al. (2003).

Regarding the calculation of the energy consumed by machinery and equipment, the methodology used was the one by ANGONESE et al. (2006), CAMPOS et al. (2009), CAMPOS et al. (2004), CAMPOS et al. (2003) and JASPER et al. (2010), which consists in applying a depreciation method based on energy, like the economic depreciation, that, based on the machinery and equipment mass depreciates them during their lifespan. In Table 2, the ratio of machines and implements used in the studied system is shown.

TABLE 2. Machinery and implements used in the swine deep bed production system.

\begin{tabular}{lccc}
\hline Machinery and implements & Quantity & Power $(\mathbf{k W})$ & Weight $(\mathbf{k g})$ \\
\hline Agrale Tractor 4100-4 & 01 & 11 & $1,260.00$ \\
Blade PTU 50 & 01 & Not applied & 185.00 \\
\hline
\end{tabular}

Considering that electricity consumption $(\mathrm{kWh})$ of the unit of production was estimated based on electrical equipment used in the production shed for swine deep bed, in Table 3 below these devices and their respective amounts and powers (in $\mathrm{kW}$ ) are described.

TABLE 3. Electrical equipment used in the swine deep bed production system.

\begin{tabular}{lccc}
\hline Electrical equipment & Quantity & $\begin{array}{r}\text { Power by unit } \\
(\mathbf{k W})\end{array}$ & $\begin{array}{c}\text { Total power } \\
(\mathbf{k W})\end{array}$ \\
\hline Fan 0.5 cv & 6 & 0.368 & 2.207 \\
Nebulization pump 3.0 cv & 1 & 2.207 & 2.207 \\
Motor thread conveyor $1.0 \mathrm{cv}$ & 1 & 0.736 & 0.736 \\
Lamps 45 W & 8 & 0.045 & 0.360 \\
Karcher pump 7.5 cv & 2 & 5.518 & 11.036 \\
\hline
\end{tabular}

\section{RESULTS AND DISCUSSION}

Table 4 presents the average measurements of the input and output components of direct energy used for the calculation of the analysis of energetic efficiency. 
TABLE 4. Average quantification of the input and output energetic compounds, directly involved in the swine deep bed production system.

\begin{tabular}{lc}
\hline Input components (direct energy) & Quantity \\
Ration, kg MN & 248.000 \\
Piglets, kg MN & 38.400 \\
Substrate used as bed (sawdust), kg MN & 34.704 \\
Electricity, kWh & $5.362,06$ \\
Fuels, L & 2.25 \\
Lubrificants, L & 0.14 \\
Grease, kg & 0.06 \\
Water, m & 864.05 \\
Human labor, hours & 781.25 \\
\hline Output components & \\
\hline Swine deep bed, kg MN & \\
Alive swine for slaughter, kg MN & \\
\hline${ }^{1}$ kg MN = kilogram of the natural material. & 69.120 \\
\end{tabular}

Regarding the structure of the shed, which is part of the category of indirect energy (energy input), ANGONESE et al. (2006) pointed out that, besides being difficult to determine an average standard of rural buildings, to find energy coefficients compatible with the Brazilian rural reality, represents an extremely arduous task. Accordingly, as reported in Table 5 and based on the these researchers conclusions, quantifications and energy coefficients of the different materials used in the construction of pig building were determined.

TABLE 5. Energy consumption (EC) in the building of the swine deep bed production system.

\begin{tabular}{|c|c|c|c|c|c|}
\hline \multicolumn{2}{|c|}{ Specie/Material } & \multirow{2}{*}{$\frac{\text { Measurement }}{\mathrm{m}^{3}}$} & \multirow{2}{*}{$\begin{array}{c}\text { Quantity } \\
3.68\end{array}$} & \multirow{2}{*}{$\frac{\mathbf{E C} \text { (MJ Ud }}{641.64}$} & \multirow{2}{*}{$\begin{array}{c}\mathbf{E C}(\mathbf{M J}) \\
2.361 .24\end{array}$} \\
\hline & Foundation & & & & \\
\hline Concrete & Floor & $\mathrm{m}^{2}$ & 1.670 .08 & 86.33 & 128.619 .61 \\
\hline Wall & $\begin{array}{l}\text { Roof walls } \\
\text { masonry }\end{array}$ & $\mathrm{m}^{2}$ & 300.30 & 1.208 .17 & 362.807 .41 \\
\hline & & $\mathrm{kg}$ & 12.261 .60 & 62.78 & 769.783 .25 \\
\hline & Pillars & $\mathrm{kg}$ & 1.743 .69 & 62.78 & 109.468 .86 \\
\hline Iron & Gate & $\mathrm{kg}$ & 157.80 & 62.8 & 9.906 .68 \\
\hline & Divisions & $\mathrm{kg}$ & 2.751 .00 & 62.78 & 172.707 .78 \\
\hline Roof & $\begin{array}{l}\text { Fiber cement } \\
\text { tiles } 6 \mathrm{~mm}\end{array}$ & $\mathrm{~kg}$ & 32.109 .77 & 3.93 & 126.191 .40 \\
\hline Water tank & Fiber cement & $\mathrm{kg}$ & 66.00 & 3.93 & 259.38 \\
\hline Pipeline & PVC & $\mathrm{kg}$ & 290.00 & 119.99 & 34.797 .10 \\
\hline Electrical & Wires and & $\mathrm{kg}$ & 7.83 & 45.02 & 352.51 \\
\hline Plastic curtains & Canvas & $\mathrm{kg}$ & 204.00 & 130.04 & 26.528 .16 \\
\hline Sum of structures & - & - & - & - & 1.743 .783 .37 \\
\hline
\end{tabular}

Thus, it follows that the shed for the production of swine deep bed consumed a total of $1.743 .783,37 \mathrm{MJ}$ in its construction (Table 5). Considering the total useful floor area of this building $\left(1489.86 \mathrm{~m}^{2}\right)$, the energy index was determined to $1170.43 \mathrm{MJm}^{-2}$. This result is slightly higher than the observed by ANGONESE et al. (2006) that in a study of the energy efficiency of a production hall of finishing pigs found an energy index of 956.03 $\mathrm{MJm}^{-2}$. CAMPOS et al. (2003) have analyzed a masonry building with an aerial suspended structure in concrete for storage of hay and obtained the energy ratio of $622.23 \mathrm{MJm}^{-2}$. 
Tables 6 and 7 show, respectively, the results concerning the energy consumed (inputs) and converted (outputs) in a production system of swine deep bed during the cycle period of 94 days.

As shown in Table 6, the energy applied in the system, the higher consumption was observed in the direct energy, with $99.71 \%$ of the total, and $0.29 \%$ for indirect energy. These results are corroborated by ANGONESE et al. (2006), \& SANTOS \& LUCAS JUNIOR (2004) and SOUZA et al. (2009) that also showed higher consumption in the category of direct energy.

TABLE 6. Consumed energy (MJ) in the swine deep bed production system during the cycle of a 94-day period.

\begin{tabular}{lcc}
\hline Energy description & CE(MJ) & \% \\
\hline Total indirect energy & 15.417 .57 & 0.2946 \\
Shed structure & 14.958 .54 & 0.2859 \\
Ration silo & 445.39 & 0.0085 \\
Machinery and equipment & 13.64 & 0.0003 \\
Total direct energy & 5.217 .496 .55 & 99.7054 \\
Ration & 4.216 .000 .00 & 80.5670 \\
Piglets & 353.664 .00 & 6.7585 \\
Sawdust & 622.936 .80 & 11.9042 \\
Electricity & 19.303 .41 & 0.3689 \\
Fuels & 106.83 & 0.0020 \\
Lubrificants & 8.04 & 0.0002 \\
Water & 2.047 .79 & 0.0391 \\
Human labor & 3.429 .68 & 0.0655 \\
Consumed Energy (Input), MJ & $\mathbf{5 . 2 3 2 . 9 1 4 . 1 2}$ & $\mathbf{1 0 0}$ \\
\hline
\end{tabular}

TABLE 7. Converted energy (MJ) in the swine deep bed production system during the cycle of a 94-day period.

\begin{tabular}{ccc}
\hline Energy description & CE(MJ) & \% \\
\hline Swine deep bed (organic fertilizer) & 1.005 .696 .00 & 46.5468 \\
Alive swine for slaughter & 1.154 .915 .58 & 53.4532 \\
Produced Energy (Output), MJ & $\mathbf{2 . 1 6 0 . 6 1 1 . 5 8}$ & $\mathbf{1 0 0}$ \\
\hline
\end{tabular}

In Table 6, it is shown the preponderance of direct energy through ration (80.57\%) used as animals' food. This result is very similar to that found by SOUZA et al. (2009) that have studied the energy balance in a swine production system cycle and have pointed out that the full ration corresponded to $80.26 \%$ of the direct energy consumed. For this same parameter, ANGONESE et al. (2006) have evaluated the energy efficiency of such system in the finishing phase and have found out that the ration represented $95.28 \%$ of the total direct energy. In that same line of thought, SANTOS \& LUCAS JUNIOR (2004) worked with the energy balance in broiler sheds and also showed that the diet was the largest component of energy intake, representing $86.50 \%$ of all the energy consumed directly by farming system.

In terms of direct energy category, the substrate used as bedding (sawdust) accounted for $11.90 \%$, as shown in Table 6. SANTOS \& LUCAS JUNIOR (2004) reported that wood shavings used as bedding accounted for $10.2 \%$ of the total direct energy invested in a broiler shed.

Another parameter belongs to the class of direct energy, piglets, corresponding to $6.76 \%$ (Table 6) of energy consumed by the swine deep beds. In ANGONESE et al. (2006) research, piglets accounted for $4.56 \%$ of the direct energy consumed by the production unit of finished pigs.

According to Table 6, the direct energy represented by fuels, lubricants, water and human labor was negligible in this study, and although they were computed in the calculation of energy 
matrix, their shareholdings in percentage showed values close to zero, making a total of $0.11 \%$ when combined. Given these parameters, SANTOS \& LUCAS JUNIOR (2004) obtained a sum of $0.14 \%$.

Moreover, concerning the use of fuels and lubricants, working with forage crops CAMPOS et al. (2005) and CAMPOS et al. (2004) observed that fuels and lubricants, respectively, 75.05 and $59.61 \%$ of the total energy consumption, assuming greater contribution in the direct energy of the systems studied.

However, it is important to notice that the quantification of certain energy production system components with low power consumption, in percentage terms, may cause significant economical, environmental and social impacts, such as electricity, water and derived of fossil fuels (SANTOS \& LUCAS JUNIOR, 2004).

From the total indirect energy expended per production cycle, 15417.57MJ (Table 6), the shed structure was the most significant one, with 97.02\%. ANGONESE et al. (2006) also identified similar behavior of the swine shed structure in significantly influence the indirect energy consumption.

Table 7 shows the total energy converted by the system, $2.160 .611 .58 \mathrm{MJ}$, and the swine for slaughter amounted to $1.154 .915 .58 \mathrm{MJ}$ and organic fertilizer which was represented by the swine deep bed, assumed values of 1.005.696.00 MJ.

In item power output (Table 7), the most significant component was the swine for slaughter, with $53.45 \%$ of the total energy converted. ANGONESE et al. (2006) found that pigs for slaughter accounted for $56.8 \%$ of the power outputs. SOUZA et al. (2009) found out that, from all the energy converted in the system, the energy represented by finishing pigs was equal to $55.58 \%$.

The swine deep bed assumed values of $46.55 \%$ (Table 7), of the total energy output, this result is very close to that found by SANTOS \& LUCAS JUNIOR (2004), who found for poultry litter, $46,80 \%$ of all the energy produced by the system.

Analysis of agronomic value of the swine deep bed performed at the Laboratory for the Study of Organic Soil Material - UFLA - revealed that, in terms of total nitrogen, $\mathrm{P}^{2} \mathrm{O}^{5}$ and $\mathrm{K}^{2} \mathrm{O}$, the referred compound had, respectively, $23,24.5$ and $13.8 \mathrm{~g} \mathrm{~kg}^{-1}$. Therefore, to harness the potential of fertilizer litter on the property where the study was conducted, the litter was applied directly to the soil and pasture, promoting thereby the cycling of these nutrients in their own production units and contributing to a better energy balance of the system in question.

When compared to pig slurry, the deep bed has higher dry material content, which enables greater accumulation of nutrients, and the largest proportion of $\mathrm{N}$ in organic form. Therefore, this compound should provide greater efficiency as a source of $\mathrm{N}$ to crops, due to the expected timing of the mineralization of organic $\mathrm{N}$ of the bed with the demand of $\mathrm{N}$ by crops (AITA \& GIACOMINI, 2008).

However, it is important to realize that, although it is a great organic fertilizer, the amount of deep bed to be applied, will depend on the type and chemical condition of the soil and crop requirements to be implemented (KIEHL, 2010), because when swine waste are added in doses higher than the retention capacity of the soil, they spend fertilizer pollutants, altering the soil quality, and especially the water (GATIBONI et al., 2008).

As described above, all of the energy involved in shed of swine deep bed, 5,232,914.12MJ refers to the energy consumed (Table 6), while the energy converted (Table 7) corresponds to $2,160,611.58 \mathrm{MJ}$, resulting in an energy ratio of 0.41 or $41 \%$, i.e., for every $100 \mathrm{MJ}$ of energy imported by the pig shed, $41 \mathrm{MJ}$ of energy produced is obtained. According to ANGONESE et al. (2006), SANTOS \& LUCAS JUNIOR (2004) and SOUZA et al. (2009), a coefficient of efficiency ( $\eta$ ) less than "a" denotes an important system, virtually all the energy consumed in the production 
process, this characteristic of systems with high technification, such as swine and poultry production.

In the system studied, the average amount of energy required to produce $1 \mathrm{~kg}$ of live pigs was equal to $41.73 \mathrm{MJ}$. In turn, SOUZA et al. (2009) reported the value of 53.35MJ to produce $1 \mathrm{~kg}$ of finishing pig.

Table 8 briefly presents all the energy inputs and outputs, directly and indirectly, and energy efficiency of the system studied.

TABLE 8. Energetic efficiency of the compounds of the input/output relation for the swine deep bed production system.

\begin{tabular}{lc}
\hline Input/Output Sources & Energetic Coefficient (MJ) \\
\hline Inputs & \\
Total direct energy & 5.217 .496 .55 \\
Total indirect energy & 15.417 .57 \\
Entrance Total & 5.232 .914 .12 \\
\hline Outputs & \\
Swine & 1.154 .915 .58 \\
Deep bed & 1.005 .696 .00 \\
Output total & 2.160 .611 .58 \\
\hline Energetic efficiency & 0.41 \\
\hline Energy to produce a kilo of alive swine & 4.73 \\
\hline
\end{tabular}

In the same line of thought, SANTOS \& LUCAS JUNIOR (2004), who studied the energy balance in broiler shed, point out that it is common to find similar units of pig production in deep bed consuming and / or producing different amounts of energy and this may be correlated with the different types of facilities, equipment and management practices.

In the case of pigs that die during the breeding process, an opportunity to increase the energy converted (output) in the form of compost (manure), is through the realization of composting carcasses of these animals (CURCI et al., 2007; SANTOS \& LUCAS JUNIOR, 2004). Furthermore, composting of dead animals contributes to the inactivation of pathogenic bacteria, viruses and parasites (CURCI et al., 2007; ORRICO JUNIOR et al., 2010).

The biogas production from swine deep bed would be another possibility of increasing the energy converted in the production system. Thus, considering the same data regarding the potential of biogas production from poultry litter, which, according to SANTOS \& LUCAS JUNIOR (2004) is $0.1001 \mathrm{~m}^{3} \mathrm{~kg}^{-1}$ that at the end of each batch, $69.120 \mathrm{~kg}$ of swine deep beds are produced, where $6918.91 \mathrm{~m}^{3}$ of biogas could be retrieved.

This biogas production figure as a saving option for the swine producer, since the chemical energy from biogas may be converted into thermal energy and / or power, which could be used to supply the Institute's own farm. Finally, the process of anaerobic digestion of waste biomass, such as the swine deep bed, is a chance to add value to waste, promoting the generation of two products (biogas and bio fertilizer) and a service (carbon credits), which can promote the generation of positive impacts in the economical, environmental, social and agronomic scopes (BLEY JUNIOR et al., 2009) .

\section{CONCLUSION}

The most significant component in the energy production system of swine deep bed was food.

The production system in question is framed in an agro ecosystem characteristics of industrial, importing most of the energy consumed in the production process and exporting over 
$53 \%$ of production in the form of pigs for slaughter, while the remaining energy converted is used within the production unit, in the form of organic fertilizer (swine deep bed).

Further studies are needed to increase the data available in the literature on energy efficiency of agricultural activities, particularly in the pig holding sector.

\section{ACKNOWLEDGMENTS}

To CAPES for granting the scholarship for the first author. To Fazenda Penalva, that contributed for this research. To Professor Vitor Hugo Teixeira from the UFLA Department of Engineering, for his assistance in this work. To CNPq for the financial support and grant of the Productivity Research scholarship for the second author.

\section{REFERENCES}

ANGONESE, A.R; CAMPOS, A.T.; WELTER, R.A. Potencial de redução de emissão de equivalente de carbono de uma unidade suinícola com biodigestor. Engenharia Agrícola, Jaboticabal, v.27, n.3, p.648-657, set./dez. 2007.

ANGONESE, A.; CAMPOS, A.T.; ZACARKIM, C.E. et al. Eficiência energética de sistema de produção de suínos com tratamento dos resíduos em biodigestor. Revista Brasileira de Engenharia Agrícola e Ambiental, Campina Grande, v.10, n.3, p.745-750, jul./set. 2006.

BIAGGIONI, M.A.M.; BOVOLENTA, F.C. Balanço energético comparativo para rotas de escoamento de soja. Engenharia Agrícola, Jaboticabal, v.30, n.4, p.587-599, jul./ago. 2010.

BLEY JÚNIOR, C.; LIBÂNIO, J.C.; GALINKIN, M. et al. Agroenergia da biomassa residual: perspectivas energéticas, ambientais e socioeconômicas. 2. ed. Foz do Iguaçu: Techno Politik, 2009. 140p.

BRASIL. Ministério de Minas e Energia. Balanço Energético Nacional 2011: ano base 2010. Brasília: MME/EPE, 2011. 266p.

CAMPOS, A.T.; KLOSOWSK, E.S.; SOUZA, C.V. et al. Análise energética da produção de soja em sistema plantio direto. Global Science and Technology, Rio Verde, v.2, n.2, p.38-44, mai./ago. 2009.

CAMPOS, A.T.; SAGLIETTI, J.R.C.; CAMPOS, A.T. et al. Análise energética na produção de feno de Cynodon dactylon (L.) PERS. Engenharia Agrícola, Jaboticabal, v.25, n.2, p.349-358, mai./ago. 2005.

CAMPOS, A.T.; SAGLIETTI, J.R.C.; BUENO, O.C. et al. Balanço energético na produção de feno de alfafa em sistema intensivo de produção de leite. Ciência Rural, Santa Maria, v.34, n.1, jan./fev. 2004.

CAMPOS, A.T.; SAGLIETTI, J.R.C.; CAMPOS, A.T. et al. Custo energético de construção de uma instalação para armazenagem de feno. Ciência Rural, Santa Maria, v.33, n.4, 667-672, jul./ago. 2003.

CONDÉ, E.S. Anuário Estatístico de Juiz de Fora 2006. Juiz de Fora: Centro de Pesquisas Sociais, Universidade Federal de Juiz de Fora, 2006. 180p.

CORRÊA, E.K.; BIANCHI, I.; PERONDI, A. et al. Chemical and microbiological characteristics of rice husk bedding having distinct depths and used for growing-finishing swine. Bioresource Techology, Essex, v.100, n.21, p.5318-5322, nov. 2009.

CORRÊA, E.K.; LUCIA JÚNIOR, T.; GIL-TURNES, C. et al. Efeito de diferentes profundidades de cama sobre parâmetros ambientais para suínos em crescimento e terminação. Revista Brasileira de Engenharia Agrícola e Ambiental, Campina Grande, v.12, n.5, p.540-545, set./out. 2008. 
COSTA, Z.F.; BUENO, O.C. Análise das eficiências energética e econômica da produção de leite bovino em explorações familiares na região de Botucatu, estado de São Paulo. Revista de Economia Agrícola, São Paulo, v.57, n.2, p.37-48, abr./mai./jun. 2010.

COSTA, O.A.D.; AMARAL, A.L. do; LUDKE, J.V. et al. Desempenho, características de carcaça, qualidade da carne e condição sanitária de suínos criados nas fases de crescimento e terminação nos sistemas confinado convencional e de cama sobreposta. Ciência Rural, Santa Maria, v.38, n.8, p.2307-2313, nov. 2008.

CURCI, V.C.L.M.; DUTRA, I.S.; DÖBEREINER, J. et al. Pré-compostagem de cadáveres de bovinos acometidos pelo botulismo. Pesquisa Veterinária Brasileira, Rio de Janeiro, v.27, n.4, p.157-161, abr. 2007.

DAGA, J.; CAMPOS, A.T.; FEIDEN, A. et al. Análise da adequação ambiental e manejo dos dejetos de instalações para suinocultura em propriedades na região oeste do Paraná. Engenharia Agrícola, Jaboticabal, v.27, n.3, p.587-595, set./dez. 2007.

FRIGO, M.S.; FRIGO, E.P.; BUENO, O.C. et al. Custos energéticos do agroecossistema pinhãomanso e milho: comparativo entre o sistema de condução de sequeiro e o irrigado. Revista Energia na Agricultura, Botucatu, v.26, n.2, p.87-102, abr./jun. 2011.

GATIBONI, L.C.; BRUNETTO, G.; KAMINSKI, J. et al. Formas de fósforo no solo após sucessivas adições de dejeto líquido de suínos em pastagem natural. Revista Brasileira de Ciência do Solo, Viçosa, v.32, n.4, p.1753-1761, jul/ago. 2008.

GIACOMINI, S.J.; AITA, C. Cama sobreposta e dejetos líquidos de suínos como fonte de nitrogênio ao milho. Revista Brasileira de Ciência do Solo, Viçosa, v.32, n.1, p.195-205, jan/fev. 2008.

JASPER, S.P.; BIAGGIONI, M.A.M.; SILVA, P.R.A. et al. Análise energética da cultura do crambe (Crambe abyssinica Hochst) produzida em plantio direto. Engenharia Agrícola, Jaboticabal, v.30, n.3, p.395-403, mai./jun. 2010.

KIEHL, E.J. Novo fertilizantes orgânicos. Piracicaba: Editora Degaspari, 2010. 248p.

KUNZ, A.; MIELE, M.; STEINMETZ, R. Advanced swine manure treatment and utilization in Brazil. Bioresource Technology, Essex, v.100, n.22, p.5485-5489, nov. 2009.

MELO, D.; PEREIRA, J.O.; SOUZA, E.G. et al. Balanço energético do sistema de produção de soja e milho em uma propriedade agrícola do Oeste do Paraná. Acta Scientiarum Agronomy, Maringá, v.29, n.2, p.173-178, 2007.

ORRICO JÚNIOR, M.A.P.; ORRICO, A.C.A.; LUCAS JÚNIOR, J. Produção animal e o meio ambiente: uma comparação entre potencial de emissão de metano dos dejetos e a quantidade de alimento produzido. Engenharia Agrícola, Jaboticabal, v.31, n.2, p.399-410, mar./abr. 2011.

ORRICO JÚNIOR, M.A.P.; ORRICO, A.C.A.; LUCAS JÚNIOR, J. Compostagem dos resíduos da produção avícola: cama de frangos e carcaças de aves. Engenharia Agrícola, Jaboticabal, v.30, n.3,p.538-545, jun. 2010.

PIMENTEL, D. Handbook of energy utilization in agriculture. Boca Raton: CRC Press, 1980. $475 p$.

SANTOS, R.R.; SIMON, E.J. Análise energética do milho em sistema de plantio direto, no assentamento rural da Fazenda Pirituba, Itaberá/SP. Revista Energia na Agricultura, Botucatu, v.25, n.1, p.121-137, jan./mar. 2010.

SANTOS, T.M.B.; LUCAS JÚNIOR, J. Balanço energético em galpão de frangos de corte.

Engenharia Agrícola, Jaboticabal, v.24, n.1, p.25-36, jan./abr. 2004. 
SOUZA, C.V.; CAMPOS, A.T.; BUENO, O.C. et al. Análise energética em sistema de produção de suínos com aproveitamento dos dejetos como biofertilizante em pastagem. Engenharia Agrícola, Jaboticabal, v.29, n.4, p.547-557, out./dez. 2009.

TAIT, S.; TAMIS, J.; EDGERTON, B. et al. Anaerobic digestion of spent bedding from deep litter piggery housing. Bioresource Technology, Essex, v.100, n.7, p.2210-2218, apr. 2009. 